\title{
EVOLUTION OF AGRICULTURAL MECHANIZATION IN VIETNAM:
}

INSIGHTS FROM A LITERATURE REVIEW AND MULTIPLE ROUNDS OF A FARM HOUSEHOLD SURVEY

\section{HIROYUKI TAKESHIMA, YANYAN LIU, CUONG VAN NGUYEN, AND IAN MASIAS}

Vietnam has experienced rapid growth in agricultural mechanization lately; particularly in the use of tractors and combine-harvesters. A recent IFPRI study documented the evolution of the growth of mechanization in Vietnam based on an extensive review of the existing literature and several rounds of a nationally representative household survey. The level of tractor use in Vietnam was relatively high in the 1970s and the early 1980s but declined through the late-1980s before it started taking off again in the 1990s. The relatively high level of tractor uses up to the early1980s were partly due to political and military reasons, as both the West and the Soviet Union gave substantial support in providing heavy machinery, including tractors. In this note, we focus on the evolution of mechanization from 1990s to 2000s.

\section{SUB-NATIONAL VARIATIONS IN MACHINE RENTAL AND OWNERSHIP}

Figure 1 plots the proportion of households that owned tractors, rented machinery, or hired labor from 1992 to 2008. While we do not see much change in tractor ownership, the percentage of cultivating households that rented machines more than tripled, from 19 percent in 1992 to 63 percent in 2008. The percentage of households that hired labor also increased sharply from 32 percent in 1992 to 55 percent in 2008.

Table 1 reports proportions of farm households that rented machinery by region and their changes between 1992 and 2008. The Mekong and Red River deltas are the main regions of rice production and the most populated areas in Vietnam. The Mekong River delta had the highest machinery rental rate (49 percent) in 1992 and has remained one of the most mechanized areas since. However, the Red River Delta became the most prevalent machinery rental region from 2004-2008 (80-85 percent). Machinery rental has also grown substantially in the Central Highlands, increasing to 55 percent in 2008 . This region has the lowest population density and it is the main production area for cash crops. The pattern in the Central Highlands is consistent with the hypothesis that mechanization helps the growth of larger-farms in relatively land-abundant areas where market access is good. Unsurprisingly, the mountainous Northwest region had the lowest rate at 27 percent in 2008.

Table 2 reports the proportion of households that owned tractors by region from 1992 to 2008. Tractor ownership was consistently low except for the Central Highlands where about 13 percent households owned tractor in 2008. In other regions, the tractor owning households accounted for less than 2 percent in 2008.

\section{DEMAND SIDE FACTORS}

\section{Farm Size and Mechanization}

Figure 1 shows the relationship between machinery rental and rice planting areas in 1992 and 2008. Machine rentals are significantly positively associated with farm size in both rounds. This indicates that the complementarity between land and machines have remained important. However, the slope of the curve for 2008 is flatter than the slope of the curve for 1992, suggesting that machine rental has increased more among small farms.

\section{Wage and Mechanization}

The rapid wage growth is likely an important driver of mechanization growth. Real wages increased significantly from 1992 to 1998 and leveled off from 1998 to 2004, probably reflecting the lagged effects of the Asian financial crisis of 1997/1998. From 2004 to 2008 , the real wage again picked up rapidly, at a rate even faster than seen during 1992-1998.

To more formally explore the factors associated with machine use, we estimate machine use as a linear function of wage, farm size and household characteristics while controlling for household fixed effects and region-specific time effects using three household panels (1992/98, 2002/04, and 2006/08) separately. The results suggest that machine use did not respond to real agricultural wage in the 1990s' or the early 2000s' panel. In contrast, machine use significantly increases in the real wage in the 2006/2008 panel, suggesting higher wage is associated with higher mechanization adoption in later 2000s.

\section{SUPPLY SIDE FACTORS}

The manufacture and hiring services are largely provided by private sectors in Vietnam since 1990s. Governments have played a very limited role.

\section{Machinery Production}


Currently, tractors are largely marketed by the private sector, which supplies both new and used machines, provides repair / maintenance services as well as some extension / training and credit services for prospective machine owners. Vietnamese-manufactured power tillers have been substituting imported power tillers since the 1990s. Domestic manufacturers have been expanding their supply networks and likely providing spare parts. The Japanese company, Kubota, has been making inroads into the Vietnamese market for $4 \mathrm{wt}$ and combine-harvesters. Kubota tractors sold in Vietnam are, however, modified to be much stronger and durable than those used in Japan. This is because while there is only one production season per year in Japan, Vietnam typically has two or three production seasons per year and tractors are used extensively throughout the year.

\section{Custom Hiring Service Provisions}

Tractor plowing services were privatized after Resolution No. 10 was instituted in 1988, which initiated the process of de-collectivization. By 1999, tractors were predominantly owned by individual farming households -88 percent for large tractors, 97 percent for power tillers, and 98 percent for diesel engines. In Vietnam today, $2 \mathrm{wt}$ are widely used and account for the majority of tractors. The low cost of $2 \mathrm{wt}$ suggests that ownership is not solely restricted to wealthy households, but also affordable to middleincome households. As a result, the roles of cooperatives that allow joint ownership of tractors may be less significant. There has also been a significant decrease in the price of land preparation services after small tractors ( $12 \mathrm{hp}$ ) were introduced and replaced big tractor (50 hp).

\section{SUMMARY OF FINDINGS}

The mechanization patterns in Vietnam have been highly divergent across regions, characterized by the growth in the smallholder-dominated deltas and the land-abundant regions of Central Coast. Machine use has been largely enabled by rentals rather than ownership. While machinery use and tractor ownership was originally concentrated among larger farmers, they have gradually spread to smaller farms, enabling many smallholders to stay competitive in the face of rising farm wages.

Since the economic and social reform in the late 1980s, the private sector has rapidly emerged as the major player in meeting the demand for greater farm power use in Vietnam. The fast pace of growth of the power tiller manufacturing industry during the 1990 s and the shift from smaller combines to larger combine-harvesters in the last several years, is largely consistent with the predictions in earlier literature that the supply side is generally not a major constraint for mechanization growth in developing countries, compared to the demand side constraints even in the transition countries like Vietnam.

\section{POLICY IMPLICATIONS}

Our study suggests that, in low-income developing countries, machine rental (rather than ownership) is likely the major channel for smallholders to use machinery. To promote custom hiring service provisions, machinery should be modified to fit the local needs and affordable spare parts, repairs and trainings should also be provided.

Vietnam's experiences suggest that demand side factors are more important than the supply side factors. Under the centrally planned economy, tractor adoption rates in Vietnam reached moderately high levels by 1980 (close to 30 percent of the entire country and even higher in Southern Vietnam). Such exposures to mechanization might have contributed to the resurgence of tractors in the 1990s. Substantial public investments including those in agricultural R\&D and irrigation infrastructure, as well as the acceleration of the economic transformation in the county, are likely to have stimulated the demand for machine use after the economic and social reforms in the late 1980s which enabled the transition of Vietnam to a market economy.

Most low-income countries have not been exposed to such high-level of machinery adoption as Vietnam and have lower total factor productivity. Therefore, they are likely faced with more demand constraints. Public investments including those in agricultural $R \& D$ and irrigation infrastructure can help increase demand for machinery especially among smallholders.

In Vietnam, the supply side has not been a major constraint for mechanization growth. However, in countries with lower demand, improving information and transportation infrastructure and providing low-cost machinery hiring services may help promote adoption of mechanization.

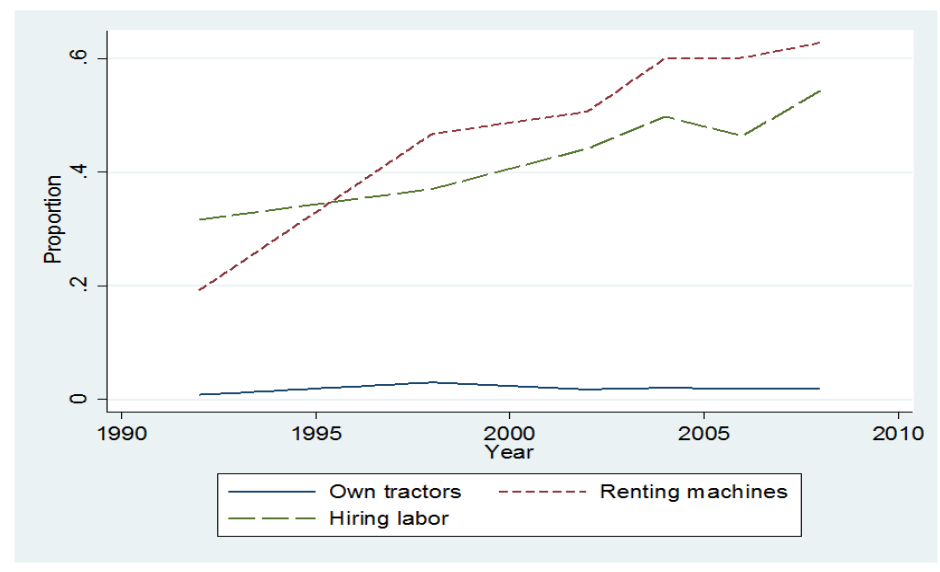

Figure 1. Trend of tractor ownership, machine renting, and labor hiring for all farming operations in Vietnam, 1992-2008

Source: Authors' calculations based on VLSS.

aproportion is in terms of households, and not weighted by areas. 


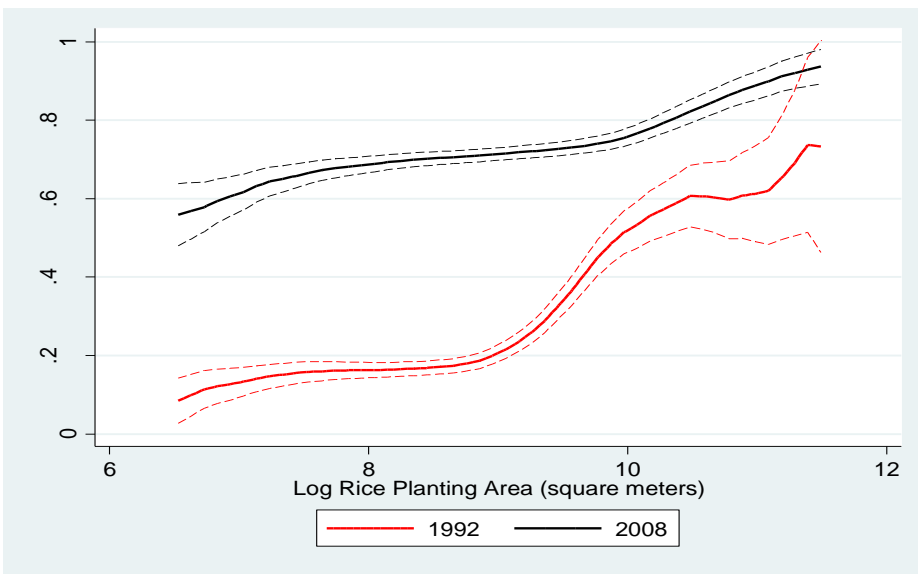

Figure 2. Relationship between machine rental and rice planting area for 1992 and 2008

Source: Authors' calculations based on VLSS.

Note: The dotted lines show the 95 percent confidence intervals around the point estimates.

Table 2. Proportion of machine rental by region, 1992-2008

\begin{tabular}{lrrrrrr}
\hline Regions & 1992 & 1998 & 2002 & 2004 & 2006 & 2008 \\
\hline Red river delta & 0.130 & 0.577 & 0.705 & 0.803 & 0.816 & 0.853 \\
North East & 0.005 & 0.269 & 0.210 & 0.305 & 0.383 & 0.421 \\
North West & 0.110 & 0.168 & 0.190 & 0.230 & 0.288 & 0.272 \\
North Central Coast & 0.260 & 0.300 & 0.585 & 0.659 & 0.679 & 0.727 \\
South Central Coast & 0.114 & 0.457 & 0.629 & 0.675 & 0.702 & 0.761 \\
Central Highlands & 0.033 & 0.380 & 0.376 & 0.588 & 0.535 & 0.546 \\
South East & 0.063 & 0.489 & 0.431 & 0.507 & 0.444 & 0.459 \\
Mekong river delta & 0.491 & 0.699 & 0.713 & 0.742 & 0.690 & 0.668 \\
\hline
\end{tabular}

Source: Authors' estimations based on VLSS and VHLSS
Table 2. Tractor Ownership by region, 1992-2008

\begin{tabular}{|c|c|c|c|c|c|c|}
\hline Regions & 1992 & 1998 & 2002 & 2004 & 2006 & 2008 \\
\hline Red river delta & 0.001 & 0.002 & 0.008 & 0.010 & 0.006 & 0.008 \\
\hline North East & 0.003 & 0.004 & 0.009 & 0.012 & 0.011 & 0.012 \\
\hline North West & 0.000 & 0.000 & 0.006 & 0.000 & 0.003 & 0.000 \\
\hline North Central & & & & & & \\
\hline Coast & 0.002 & 0.002 & 0.010 & 0.006 & 0.009 & 0.002 \\
\hline South Central & & & & & & \\
\hline Coast & 0.003 & 0.012 & 0.007 & 0.010 & 0.010 & 0.009 \\
\hline Central Highlands & 0.099 & 0.212 & 0.099 & 0.116 & 0.125 & 0.128 \\
\hline South East & 0.014 & 0.069 & 0.025 & 0.025 & 0.025 & 0.020 \\
\hline Mekong river delta & 0.016 & 0.028 & 0.014 & 0.021 & 0.018 & 0.020 \\
\hline
\end{tabular}

We gratefully acknowledge funding support from Syngenta Foundation for Sustainable Agriculture and the CGIAR Research Program on Policies, Institutions, and Markets (PIM).

\section{INTERNATIONAL FOOD POLICY RESEARCH INSTITUTE \\ A member of the CGIAR Consortium | A world free of hunger and malnutrition \\ 1201 I Street, NW | Washington, DC 20005 USA \\ $\mathrm{T}:+1.202 .862 .5600 \mid \mathrm{F}:+1.202 .467 .4439$ \\ Email: ifpri@cgiar.org |www.ifpri.org}

This publication has been prepared as an output from the project - mechanization process in Asia and its implication in SSA. It has not been peer reviewed. Any opinions stated herein are those of the author(s) and are not necessarily

representative of or endorsed by the International Food Policy Research Institute.

Copyright @ 2019 International Food Policy Research Institute. All rights reserved. To obtain permission to republish, contact ifpri-copyright@cgiar.org. 
